
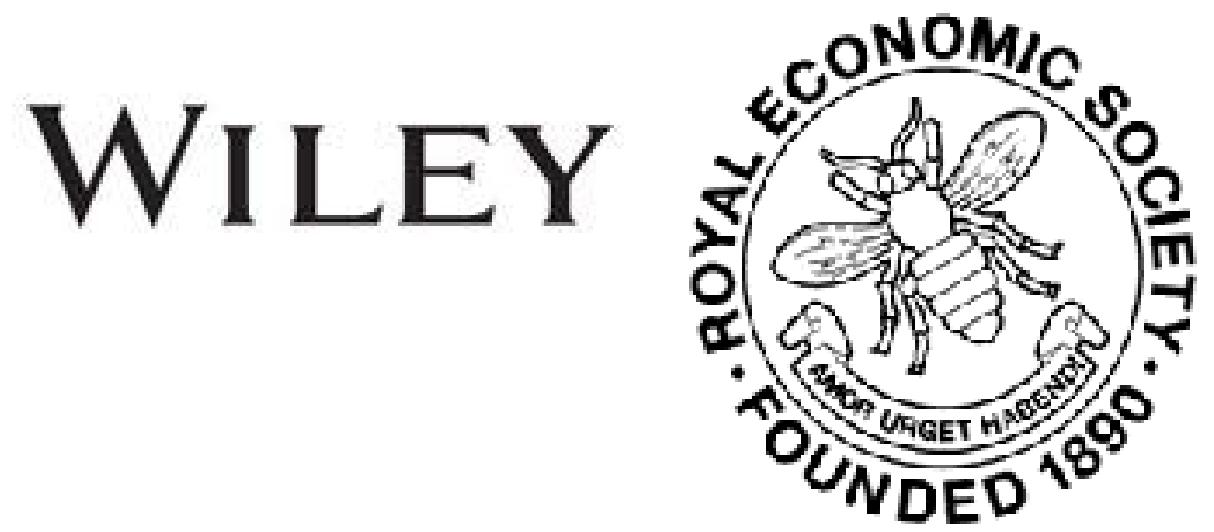

On Some Unsettled Questions of Public Credit Author(s): Gustav Cohn

Source: The Economic Journal, Vol. 16, No. 62 (Jun., 1906), pp. 212-221

Published by: Wiley on behalf of the Royal Economic Society

Stable URL: http://www.jstor.org/stable/2221279

Accessed: 26-06-2016 11:59 UTC

Your use of the JSTOR archive indicates your acceptance of the Terms \& Conditions of Use, available at

http://about.jstor.org/terms

JSTOR is a not-for-profit service that helps scholars, researchers, and students discover, use, and build upon a wide range of content in a trusted digital archive. We use information technology and tools to increase productivity and facilitate new forms of scholarship. For more information about JSTOR, please contact support@jstor.org.

Wiley, Royal Economic Society are collaborating with JSTOR to digitize, preserve and extend access to The Economic Journal 


\section{ON SOME UNSETTLED QUESTIONS OF PUBLIC CREDIT}

ON some of the most important questions of public credit there exists perfect unanimity among the authorities; on other points no such agreement exists, or the questions have never perhaps been fully discusssed. We will consider first the points which may be regarded as established :-

Public Debts are as indispensable to-day as they were a hundred years ago. The progress of modern statecraft, the scientific study of public finance and taxation, have done nothing to diminish this necessity. The most advanced of the civilised countries of the new century are just as dependent on loans as the most backward, however their requirements and conditions may differ in other respects. Thus Great Britain contracted a National Debt of 547 millions sterling between the years 1793 and 1815. In 1816 her total indebtedness amounted to 816 millions, but in 1898-9 this figure had been brought down by means of successive redemptions to 635 millions. This improvement, however, which it had taken more than eighty years to achieve, was almost entirely wiped out in the few years that have since elapsed, and in 1904-5 the debt had again risen to 797 millions. It is true that in the interval the population of the United Kingdom increased from 20 to 44 millions. Nevertheless, the yield of taxation per head of the population remained practically stationary during this period, i.e., it was 50s. per head in 1817, and 57s. in 1904-5. And there is no doubt that a more important and financially more exhausting war than the recent South African struggle would be followed to-day, just as would have been the case a century ago, by an increase in the National Debt on quite a different scale.

The truth is that a State may possess in its system of taxation ample resources for the satisfaction of its ordinary needs, but for its extraordinary requirements it must always resort to bor- 
rowing. For the limits within which it either can or will increase its revenue-whether by the imposition of new burdens or the extension of existing ones-are strictly defined, and the only alternative is an increase in the National Debt. In this respect the practice of various nations and the state of their finances vary very little, and countries in a lower stage of political development may console themselves with the reflection:- "Solamen miseris socios habuisse malorum."

The comparison cannot, however, be pushed any further. And this brings us to another point on which there exists substantial agreement, the principle, namely, that the progressive development of public credit goes hand in hand with the development of political standards. The increasing security of loans made to the State tends to facilitate their negotiation. This security, again, depends on the inviolability of the given pledge, and on the public institutions and the financial strength necessary to guarantee this inviolability. The nation which has most honourably and consistently held its promises sacred must be placed in the front rank, while at the further extreme stand those whose pledged word-whether from moral and political or from economic and financial deficiencies-is little better than a farce.

In the study of these phenomena, as in all problems of economic development, two alternative methods of comparative treatment are possible. We may take a State and trace the development of its finance and public debt throughout history, or we may study the diversity that exists at the present day, which, if we understand how to select our facts, will afford us an instructive succession of types of the different levels of progress. An instance of the extreme lower end of the scale at the present day-the counterpart, by the way, of what the civilised States of Europe were in the past-occupied the attention of the English House of Commons about thirty years ago. It was the case of those adventurous loans contracted with the assistance of some London firms on the London Stock Exchange by several Central American Republics, in the exposure of which Sir Henry James rendered signal public service. (Report of the Select Committee on Loans to Foreign States, together with the Proceedings of the Committee, Minutes of Evidence, etc., July 29th, 1875.) Among these was the loan raised by the Republic of Honduras, which for the previous forty years had been unable to pay either the interest or the principal of a debt contracted as far back as 1825 with the United States of Central America, and this although the interest amounted to no more

No. 62.- -vor. $\mathrm{xVI}$. 
than $£ 1,632$ annually. The new loan of 1867 amounted to one million sterling, and yet the ordinary revenue of the Republic, which, by the way, was absolutely indispensable for the current expenses of the Government, was already pledged in another direction. The Bonds were redeemable in fifteen years, and the interest was fixed at 10 per cent. As a matter of fact, the total sum that ever reached the bondholders in the shape either of interest or sinking fund did not exceed $£ 106,000$. The promoters and negotiators were shady characters, some of whom had a previous acquaintance with the criminal courts. In this way, and with similar results, a number of loans were raised on the London and Paris Exchanges by other Central American Republics.

Between these two extremes, with England, France, Germany, and the United States of America at one end of the scale, and the above-mentioned types of primitive barbarity at the other, we get in a graduated series all the financial administrations of the modern world. The position which a State occupies in this scale will determine the credit which it enjoys and the conditions under which it can obtain loans. A sound credit and a low rate of interest, an uncertain credit and a high rate of interest, go hand in hand.

Another point which may be regarded as settled is the influence which the demand for public money exerts on the stock market, i.e., on the conditions under which loans are raised. The rate of interest falls with a diminished demand for money and rises with increased competition. Or, to put it in a different form, loans become dearer when the public does not wish to lend, and cheaper when the stock is in general demand.

This is clearly illustrated by the fluctuations in the price of English Consols in the last ten to fifteen years. The 23 per cent. Consols reached their maximum price in 1897 (i.e., in May, 1897, the average price was $113 \frac{1}{4}$ per cent.). In the succeeding years, in response to the calls made on the English stock market by the Boer War, they fell about 20 per cent.

A similar effect in the opposite direction is produced by the growth of available capital, i.e., by that floating capital which seeks investment in State securities. Such a development has taken place in England during the past thirty years. The average yield of English railway companies on the price of their ordinary shares thirty years ago was 5 per cent.; to-day it varies from $3 \frac{1}{2}$ to $3 \frac{3}{4}$. The debentures of the same companies paid 4 per cent. where they now pay 3 per cent. The case of Consols is 
analogous; in 1874 the rate of interest was 3 per cent., and the purchasing price varied from 91 to 93 ; to-day their price is still 91 , while the interest has fallen to $2 \frac{1}{2}$.

It is clear that the general commercial activity of the country, in so far as it does or does not attract the floating capital, exerts a corresponding influence on the Exchange price and the interest on Consols. When production is active and the capital of the country is absorbed by spirited industrial and commercial enterprise, it is withdrawn from State securities and the price of these falls or the interest rises. In times of depression, on the other hand, there is less demand for capital ; a variety of undertakings have possibly ended disastrously; at any rate, capital is withdrawn from commercial enterprise. In these circumstances it seeks a home in State securities-a species of investment which is safe if not very profitable. The price of Consols rises, or, which is equivalent, the rate of interest falls.

Such are the points about which there is no dispute, the causes which admittedly govern the conditions and fluctuations of public credit and public loans. There may be other points on which it is needless to dwell at greater length, the aim of this article being to clear up the questions which have not yet been settled, and therefore require discussion.

\section{II.}

My attention was directed to these points mainly by recent events in the Far East, and their influence on the financial position of the two hostile countries. To the student of the great problems of history, and of the progressive development of nations and races, the war has proved both stimulating and instructive. So, too, with our own branch of research. We may even go further and say that the figures which represent the transformation of the national credit and the national debts of the two countries are, as it were, shorthand records of those same great changes which came upon the world like a thunderclap and have since become the subject of deep and searching investigations.

In March, 1904, the stock of the Japanese National Debt stood at 62 per cent., on August 30th, 1905, its price was 893, and it has gone up a little further since the conclusion of peace. The Russian State securities stood at par on December 15th, 1903, at $91 \frac{1}{4}$ on August 30 th, 1905, and to-day (April, 1906) their price is 82 per cent. What is the meaning of these changes? 
In the first instance they are, of course, the reflex of contemporary events, of the victories and defeats of the two Powers. In the case of Russia it was not defeat in battle only, but the internal revolutionary disturbances which proved even more clearly than the reverses on sea and land how low was the stage of development which the country had reached. It is characterisitic that the fall in securities has been even greater since the conclusion of peace than it was during the whole period covered by the war. Until then it had been possible for those who were inclined to take a charitable view of the Russian reverses to shut their eyes to the real cause of these failures. But the events of the concluding months of 1905 and later did away with all possibility of illusion on the score of Russia's political development. The revelations made by the internal disturbances which followed closely on the Russian reverses exposed once and for all the true causes at work. Whether we direct our criticism from above downwards, or from below upwards-whether we adopt the standpoint of the old powers of the State or the new, the Dynasty, the Army, the Bureaucracy, or the People, with its varied elements, social grades, and different racial origins, etc., in every case we are equally impressed with the magnitude of the problem. It is the well-known old Russian paradox - the combination of an abysmal depth of barbarism with the deceptive veneer of European civilisation.

With regard to Japan, on the other hand, we find a prevailing tendency to pronounce her financially exhausted by the war. This is due partly to the desire of certain critics of the situation to give a verdict as favourable for Russia as circumstances will permit, and partly to the effect produced on the minds of quite impartial judges by Japan's readiness to accept the surprisingly moderate terms of peace. In view of this alleged exhaustion, it is all the more astonishing that Russia, with her boundless financial resources-as a friendly critic puts it-should have sunk so low in the world's estimation, while Japan, with her exhausted exchequer, has risen so high. This remarkable contrast brings us somewhat nearer to the consideration of the causes at work, to the uncertainty that exists on some unsettled questions of public credit.

What are the causes which led to the rapid change in the market price of Russian and Japanese State securities? Certainly not the cost of the war. Else how should Japan, in spite of this expenditure, in spite of her renunciation of an indemnity, in spite of her financial exhaustion, have contrived to rise in the world's 
estimation, so far as this is expressed in a demand for her securities? The causes which we are seeking lie deeper. They are to be found in the opinion which the world holds of a nation's political standards, of the soundness of her institutions, the inviolability of her pledged word, in the last resort of the moral principles which inspire and the intellectual faculties which direct her people's activities. The change in public opinion concerning Japan is easy to explain. Her achievements in the late war concluded her period of probation, and gained her a footing in the community of civilised nations. In addition to this she has given proof of political, technical, moral, and intellectual qualities which mean much more than mere military prowess. The credit that springs from the appreciation of these facts is of more importance than any transitory financial advantage. It is strong enough to compensate, and indeed to do much more than merely compensate for her temporary monetary difficulties.

The question of the change in the Russian financial position is somewhat more complicated. Before the war with Japan there was a widespread and quite undeserved confidence in Russia which led to her inclusion in the great family of the civilised States. It may be that this did not extend to other aspects of her national life, but it did at any rate include the particular aspect with which we are here concerned. Two countries were especially affected by this view-France and Germany. France was induced to enter into that remarkable arrangement, the Franco-Russian Alliance. Germany was not on the same terms of amity with Russia, and her conduct and that of her capitalists can therefore only be ascribed to an even stronger prejudice or an even deeper ignorance of the state of Russian affairs.

It must be counted among the most surprising abnormalities of the phenomena of public credit that for a difference of $\frac{1}{2}$ per cent. in their dividends a number of German capitalists were enticed into lending their funds to the Russian Government instead of to their own. How great was the illusion from which they suffered is clearly shown by the following comparison, which recent changes have accentuated still further. The highest figure reached by Russian 4 per cent. Stock before the war was 103 per cent. In October, 1905, the Banque de Paris tendered 90 per cent. for a new issue of a thousand millions. To-day (April, 1906) there is a rumour of a new loan of $3 \frac{3}{4}$ thousand million francs to be raised in Paris, of which sum $1 \frac{1}{4}$ thousand is already subscribed. The stock will earn a dividend of 5 per cent., and is to be issued at 88 . How the rate of exchange will stand for 
subsequent portions of the great loan remains to be seen. But even an exchange rate of 88 for 5 per cent. interest as against the former maximum of 103 for 4 per cent. represents a decline in the national credit of 40 per cent. We shall return to this subject later.

This leads to another point. We must observe that it is by no means solely the opinions current among a people or even among its capitalist class regarding the trustworthiness of another nation which settle the question of credit. Definite political influences co-operate in this matter, influences which emanate from the headquarters of the borrowing State, penetrate thence to the financial powers of the lending nation, and so provide a stimulus for the investment of capital in the funds of foreign countries. The achievements of the Franco-Russian Alliance in this direction, the effects of the German prejudice, or whatever we may like to call it, in favour of Russia now seem likely to be counteracted by the influence of certain recent diplomatic events. The actual effect of such influences on the demand for the Russian loan is not easy to estimate. But to make it solely responsible for the success or failure of the negotiations is, I think, an exaggeration. Is it conceivable that after such catastrophes as we have witnessed, after such revelations into the conditions existing in the Russian Empire and among the Russian people, the judgment of foreign capitalists as to the advisability of taking up the loan should be entirely subject to the word of command of their Governments or their haute finance? Can we rate the judgment of nations and their capitalists so low as to suppose that they must be entirely guided in so important a matter by orders from headquarters? Are they politically and economically so undeveloped that their attitude must needs be that of children to their guardians, and worse, that they allow themselves to be led by their guardians in the wrong direction without bringing their own better judgment into play?

Here we touch on the central point of the problem. "The disease is the desire of people to get a high rate of interest for their money," said Baron Rothschild before the Select Committee of the House of Commons on Foreign Loans. This disease would not be what it is if the striving for an advantageous investment of capital were accompanied by a proper insight into the facts of the case, an adequate appreciation of the causes that may justify the higher rate of interest, of the circumstances that make it reasonable or the reverse. The less independence, however, 
capitalists retain in their opinions, the more these other powers, i.e., diplomacy, haute finance, the Press, the Stock Exchange, and so forth, step into the breach. It is not for everyone that the disease of which Baron Rothschild speaks is attended by dangers. For him and for his firm the desire for a high rate of interest was not only innocuous but advantageous, for it was combined with a correspondingly sound judgment. The very reverse is the case with the great majority of capitalists, whose judgment on questions of finance is so weak that they really need some kind of protection. We might establish-were such a thing possible-regulations similar to those in force for minors, whose estates are administered according to fixed principles and within the rigid limits of trusteeship.

How the capitalist classes of various countries differ in their judging capacities it is difficult to say. But we may trace certain indirect influences at work, for the disease is present in varying degrees of intensity in every country. That section of capitalists, or rather that portion of their capital which seeks investment at a high rate of interest varies inversely with the remainder of the capital which has no such desire. When a country has much floating capital, and especially when this is possessed by large owners, there is a tendency to be satisfied with a moderate rate of interest, provided this goes hand in hand with security. The greater a man's wealth the more precautions he can take in the disposition of his capital without crippling his revenue. This kind of investment has the further advantage that it leaves the possessor free from care and worry to enjoy the other interests of life. The smaller the fortune the stronger will be the owner's inducement to increase the earning power of the capital -a course generally attended by considerable risks. For the rest, a variety of causes may contribute to the popularity of a country's securities. The long standing of her constitution, the character of her institutions, the patriotic instincts of her population, a widespread conservative predilection for home investments rather than foreign enterprise-these are the causes which appear to explain the high price of British Consols (or their low rate of interest) as compared with the securities of other countries.

How can we account for the existing differences in the price of French and German Government stock? The French Republic at the present day pays 3 per cent. on its National Debt, the German Empire and the Prussian State pay $3 \frac{1}{3}$. Why? If we try to explain this by the difference in stability and security 
of the forms of government we come upon a curious paradox. France has experienced during the nineteenth century a constant repetition on a small scale of the great upheaval which brought the eighteenth century to a close; the Republican Government now in force, for more than a generation, has frequently found itself in a position so questionable as to foreshadow immediate disruption. This condition of affairs would afford a plausible explanation of the higher price of British Consols over the French rente. But we are comparing the French rente with German State securities, and the lower price of the latter can certainly not be explained by any such insecurity of German institutions as compared with French.

On the other hand, certain national characteristics of the French do undoubtedly afford an explanation of the higher price of the French rente. Such are the widespread moderation of the rank and file of small capitalists, their highly developed thriftiness and their economic skill in utilising a small income to the best advantage. Further, we find that conservative patriotic instinct which shows itself in the high value placed on home securities.

There is a consideration most significant in private financial relations, which, oddly enough, appears to play no part at all in the credit of great States. This is proved by the price of German national stock on the one hand, and of the Prussian State loans on the other. We know that the bulk of the National Debts of the present day, like those of a hundred years ago, has been incurred for unproductive purposes. The money has been required to meet the extraordinary expenditure of wars-small or great, short or tedious. Or we have the kindred needs of armed peace, with its warlike equipment on sea and land. It is quite exceptional that public loans are raised for productive purposes, and when this does happen the borrower is generally a local, not a State or a national authority. But there is one State, i.e., Prussia, whose National Debt differs entirely in character from that of other States. Her debts were contracted for productive purposes solely, as her great unproductive expenditure has for the past forty years been separated from Prussian finance and vested in the new Empire. Prussia incurred her National Debt by buying railways, and if the expenditure was in itself productive, the result of this nationalisation of railways has been completely productive also. The capital invested in railways, for which $3 \frac{1}{2}$ to $3 \frac{1}{3}$ per cent. has to be paid to the stockholders, earns 
a yearly dividend of 8-9 per cent., and has done so for a long period of years.

The German Empire, on the other hand, has gradually contracted a debt of $3 \frac{1}{2}$ thousand million marks-a sum equal to about one-half the Prussian debt-to meet the "extraordinary" needs of the equipment of its Army and Navy. The difference between the uses and the productiveness of the two debts has not in any way affected the Imperial credit or the price of its securities. As a matter of fact, the German national securities and the Prussian stock have for many years stood at the same figure. And if every now and again small differences arise they are just as likely to be in one direction as in the other.

If in the foregoing exposition the differences in the market price of the stock of various countries has been deemed worthy of investigation and discussion, there is no occasion to inquire why these differences (between England, France, and Germany) are as small as they actually are and not greater. The international stock markets ensure a certain tendency to a common level, and it is no more remarkable that this difference is comparatively small than it is that the English investor prefers English Consols to French rente or German stock, provided he can get it at the same price.

The problem to be investigated lies in another direction. Why is there any permanent difference of price at all? Why does not the price of French or German funds rise in their own markets to the same height as English Consols?

Gustav CoHn

University of Göttingen. 